\title{
Ethnomycological studies on some macro-fungi in Rupandehi District, Nepal
}

\author{
H. P. Aryal ${ }^{1}$ and U. Budathoki ${ }^{2}$
}

This ethnomycological investigation explores the wild edible microfungi with their identification and documentation of nutritional potential and indigenous knowledge. The study area occupies 154.75 hectare-land, and lies within a narrow limit of altitude between $110 \mathrm{~m}$ and $165 \mathrm{~m}$ above sea level in tropical deciduous riverine forest. Amanita caesarea, A. chepangiana, A. pantherina, Agaricus augustus, Coprinus comatus, C. plicatilis, Macrolepiota fuliginosa, M. rhacodes, Russula emetica, $R$. foetens, $R$. nigricans, Scleroderma bovista, S. citrinum, Termitomyces clypeatus and $T$. eurhizeus are found to be dominant. The collected samples represented 27 species of Basidiomycetes belonging to 6 orders, 13 families and 18 genera. The dried specimens are housed in the Tribhuvan University Central Herbarium, Kirtipur, Kathmandu, Nepal. The area embraces many mycophagous ethnic communities. The mycoelements prevailing in this area need sustainable conservation and utilization.

Key words: Basidiomycetes, macrofungi, mushroom diversity, indigenous, mushrooms

$\mathrm{N}$ epal is considered as the homeland for the mushroom floral diversity (Aryal et al., 2012). So far, 812 mushroom species have been identified (Adhikari, 2009). Out of them 228 edible (Christensen et al., 2008), 66 poisonous (Pandey, 2008; Adhikari, 2009) and 75 medicinal species (Adhikari, 2009) have been reported.

The investigation and study on mushroom of Nepal started since 19th century (Lloyd, 1808; Berkeley, 1838). Since then, several papers have been published and several botanicalinvestigations have been done. Among these, very few reveal the studies and investigation on macrofungi from western Nepal. This is a preliminary report on ethnomycological investigation carried out at Baunnakoti Community Forest in Rupandehi District. The area has not been previously investigated so far.

This paper highlights the indigenous knowledge of the wild edible mushrooms in the district. Presently, 27 species of the Basidiomycetes belonging to 6 orders, 13 families and 18 genera have been reported from Baunnakoti Community Forest, situated in the tropical climate.

\section{Materials and methods}

\section{Study area}

The study area lies in Rupandehi District of Lumbini Zone, and partial parts of Chiliya, Madhauliya, Padsari and Tikuligadh Village Development Committees (VDCs) in the Western Terai of Nepal (Fig. 1). The total human population of the study area was 32,256 (DDC, 2007) with 5,531 households (DFO, 2012). The forest vegetation is dominated by species of the Dipterocarpaceae, Combretaceae and Leguminosae families. The forest covered area of Chiliya VDC is 96.85 ha (10.45\%), followed by Tikuligadh 46.1 (2.16\%), Padsari 9.9 ha $(1.02 \%)$ and Madhauliya 1.9 ha $(0.15 \%)$. This study included $2.95 \%$ of forested land (DFO, 2012), and lies between $27.5421^{\circ}-27.5623^{\circ} \mathrm{N}$ latitudes and $83.40611^{\circ}-83.47643^{\circ} \mathrm{E}$ longitudes. The altitudinal range varies from $110 \mathrm{~m}-165 \mathrm{~m}$ above sea level. The average annual rainfall is $1,391 \mathrm{~mm}(\mathrm{GoN}, 2010)$.

' Paklihawa Campus, Bhairahawa, Institute of Agriculture and Animal Science, Tribhuvan University, Kathmandu, Nepal.

E-mail: hahariprasadaryal06@gmail.com

${ }^{2}$ Central Department of Botany, Tribhuvan University, Kathmandu, Nepal. 


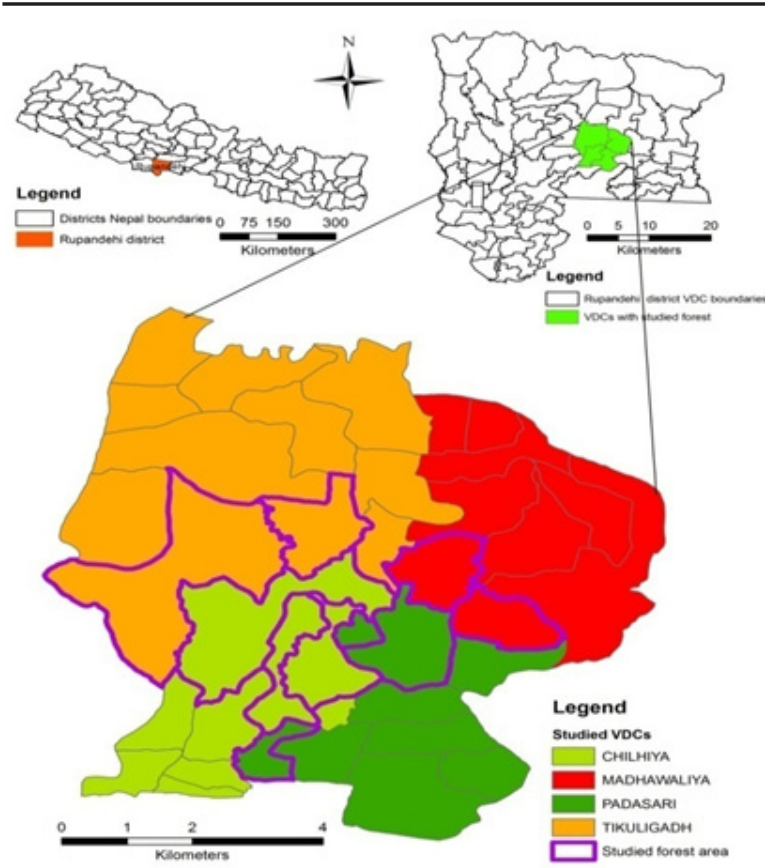

Fig. 1 : Map of the study area

The area lies in tropical zone embracing different types of vegetation and soil composition. The tropical riverine belt is composed of khair (Acacia catechu), karma (Adina cordifolia), banjhi (Anogeissus latifolia), simal (Bombax ceiba), satisal (Dalbergia latifolia), sissoo (Dalbergia sissoo), Sindure (Mallotus philippinensis), kandel (Phoenix sylvestris), sal (Shorea robusta), kusum (Schleichera oleosa), jamun (Syzygium cumini), sagwan (Tectona grandis), saj/asana (Terminalia alata) and barro (T. bellirica) etc. (Stainton, 1972; Shrestha, 1998). The diverse phytodiversity and ecological conditions provide a good homeland for the growth of tremendous parasitic, saprophytic and mycorrhizal fungi (Aryal and Budathoki, 2012). The northern belt of the area is composed of loamy sand, while the southern belt consists of sandy loam to loamy soil.

\section{Materials and methods}

Altogether, 27 mushroom samples were collected, and the local informants were interviewed. Indigenous knowledge survey was conducted from 15 to 31 May 2010, and specimens were collected from 1 June to 31 October 2011. The Participatory Rural Appraisal (PRA) technique was adopted with the local people aimed at getting information largely on nutritional aspects. Data were obtained using combined semi-structured questionnaire, participatory discussions and field observations.
Mushroom samples were photographed in their natural habitat, and their morphological characters were noted. The samples were well dried and packed in wax paper bags with proper tag numbers. The habitat including ecological parameters viz. altitude, vegetation composition, soil type, soil $\mathrm{pH}$, soil moisture, humidity, and temperature were recorded. The paper bags were brought to the Central Department of Botany, Tribhuvan University for further microscopic examination.

The identification was done with the help of relevant literatures (Bakshi, 1971; Dickinson and Lucas, 1979; Singer, 1986, Kumar et al., 1990) and websites (biodiversity library.org; Index fungorum; Jstor.org; Mycobank.org; Scircus; tropicos.org; Agaricus in the Pacific Northwest; Boletes in the Pacific Northwest). The voucher specimens were deposited in Tribhuvan University Central Herbarium.

\section{Results and discussion}

\section{Results}

During field survey, altogether, 27 species of Basidiomycetes from 6 orders belonging to 13 families and 18 genera were recorded with their brief descriptions (Annex 1).

A notable frequency of Amanita caesarea, A. chepangiana, A. pantherina, Agaricus augustus, Coprinus comatus, C. plicatilis, Macrolepiota fuliginosa, M. rhacodes, Russula emetica, $R$. foetens, $R$. nigricans, Scleroderma bovista, $S$. citrinum, Termitomyces clypeatus and T. eurhizeus were observed. Out of the total collection, 55\% mushrooms were found to be under Agaricales order followed by Polyporales, Russulales, Boletales, Hymenochaetales and Tricholomatales (Fig. 2).

\section{Indigenous knowledge and therapeutic use}

On the basis of the information collected, $92.5 \%$ of the mushrooms were found to be used as food, $5.5 \%$ as medicine, $1.5 \%$ as taste and flavor, and $0.5 \%$ as tonic. The food values of wild edible mushrooms were found to be more significant in the study sites. The consumption data revealed that mushrooms were found to be mostly used as food by $51 \%$ women followed by $31 \%$ children and $18 \%$ men. People were found to have used these mushrooms for the remedy of different 


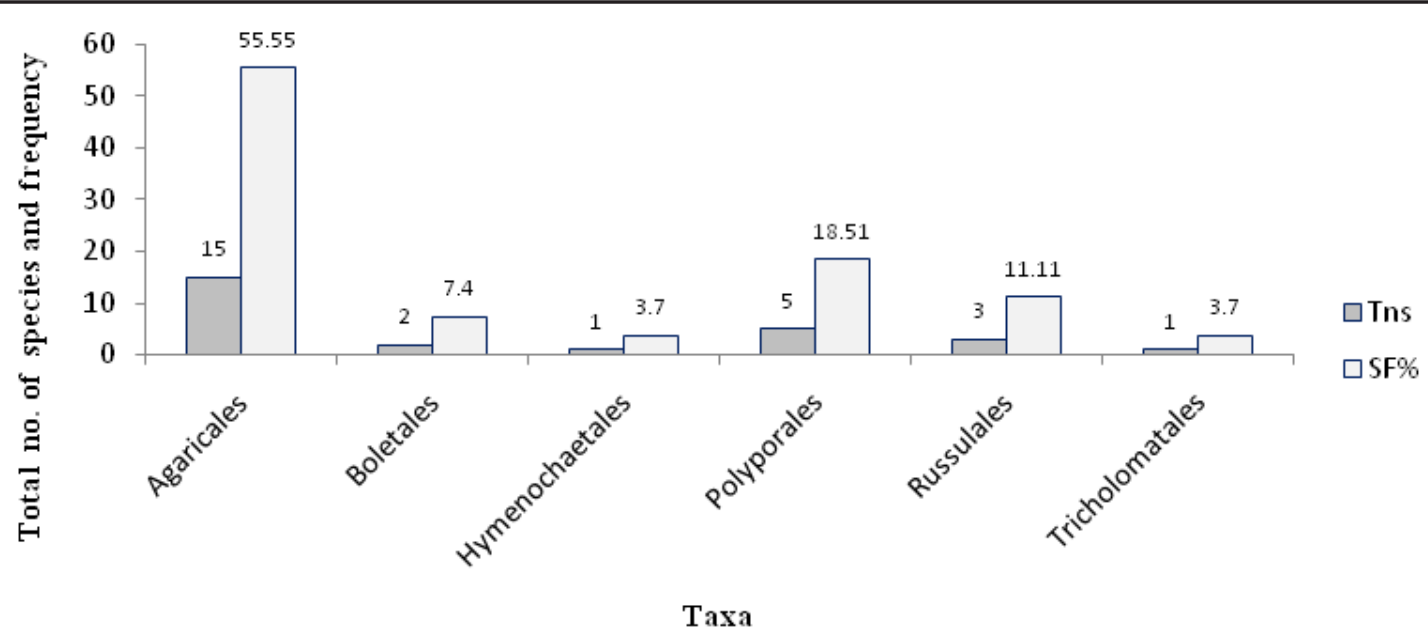

Fig. 2: A graph showing the total no. of species (Tns) and \% of frequency of groups (SF\%) of Basidiomycotina

types of diseases and ailments. Out of the 150 respondents, $30 \%$ people were found to have used it for the remedy of measles. Similarly, $24 \%$ people were found to have used it for the treatment of yellow fever, $20 \%$ for the treatment of jaundice, $16 \%$ for the treatment of inappetence, $4 \%$ for the treatment of constipation, $4 \%$ for the treatment of mumps, ear pain and cut wounds, $2 \%$ for the treatment of skin diseases, $1.3 \%$ for the treatment of muscular pain, and $0.6 \%$ for the treatment of stomach pain. Their medicinal uses for the treatment of different types of disease were found to have made them more significant for the people of the area.

\section{Discussion}

Wild edible mushrooms are not only an important source of food for local people, but are equally used for medicinal purpose. The present survey on the macrofungi revealed that there are plenty of edible species of mushroom. The most common among them such as Cleroderma bovista, T. clypeatus, T. eurhizeus and Volvorella volvacea are collected, sacked in bags and carried to market for selling.

Among 27 species identified, 15 are edible, 4 inedible, 4 poisonous and 4 species possess medicinal value. Some of the edible species such as S. bovista, T. clypeatus and T. eurhizeus are also used for medicinal purpose. The medicinally important tropical polypore like Pycnoporus cinnabarinus is used for the remedy of infectious disease (mump), ear pain etc. Scleroderma citrinum, the medicinal species is also used as food. Schizophyllum commune, the cosmopolitan inedible species is sometimes used for culinary purpose in food deficit condition. This species has religious value too, and is used as 'Sagun' i.e. good luck in the marriage ceremony in Newar community.

During surveys, it was found that the mushroom flora of Macrolepiota fuliginosa, M. rhacodes, $R$. nigricans, $T$. clypeatus, $T$. eurhizeus and $V$. volvacea is declining since the last two decades due to deterioration of forest lands. Notable frequencies of species were found in abundance during sample collection. Being saprophytic, obligatory symbionts as well as part of the mycorrhizal association, these microfungi play an important role in increasing soil fertility in the forest through biodegradation as well as decomposition of the lignocellulose compounds of leaf litter. The litter debris of vascular flora favours the regulation and maintenance of temperature and moisture in the soil for these microfungi. The toxic species listed are Amanita pantherina, Coprinus plicatilis, Russula emetica and $R$. foetens.

\section{Conclusion}

The reported mushrooms occur in tropical to temperate belts throughout the nation. Extensive investigation is needed to find out their species richness, distribution pattern, species diversity index and ethnomycological uses. Some of the important macrofungi such as Macrolepiota, Scleroderma, Termitomyces and Volvorella spp. need special attention to be conserved against threat to avoid their unmanaged and unscientific exploitation. Besides, their harvesting should be done in scientific manner rather than using traditional methods. The mycoelements prevailing 
in this area need sustainable conservation and utilization.

\section{Acknowledgments}

The authors would like to acknowledge Nepal Academy of Science and Technology for providing research grant to conduct this study. The authors are obliged to the Central Department of Botany, Tribhuvan University for providing laboratory facilities. The authors are also grateful to the Institute of Agriculture and Animal Science for granting study leave to one of them (Mr. H. P. Aryal). Further, the authors would like to appreciate Prof. Dr. R. D. Tiwari for his kind cooperation during the study period. Last but not least, sincere thanks are extended to the local people of the study area for providing information to the authors.

\section{References}

Adhikari, M. K. 2009. Researches on the Nepalese Mycoflora. Alka Basti Marga, Kathmandu, Nepal.

Aryal, H. P. and Budathoki, U. 2012. Macrofungi of Karhiya community forest, Western Terai, Nepal. Nepalese Journal of Bioscience 2: 93-97.

Aryal, H. P., Budathoki, U. and Adhikari, M. K. 2012. Mycodiversity in Peepaldanda Community Forest, Western Terai Region of Nepal. Plant Resources Bulletin 34: 13-17.

Bakshi, B. K. 1971. Indian Polyporaceae. Indian Council of Agriculture Resources, New Delhi, India.

Berkeley, M. J. 1838. Description of exotic fungi in the collection of Sir W. J. Hooker from memories and notes of J. F. Klotsch with addition and correction. Natural History 3: 375-401.
Christensen, M., Bhattarai, S., Devkota, S. and Larsen, H. O. 2008. Collection and use of wild edible fungi in Nepal. Ecology and Botany 62 (1): 12-23.

Dickinson, C. and Lucas, J. 1979. Encyclopedia of Mushrooms. Orchid Publication, London, The UK.

DDC. 2007. Rupandehi District Profile. 2007, Bhairahawa, Nepal.

DFO. 2012. District Forest Office, Rupandehi: Brief Introduction and Progress Report 2012, Bhairahawa, Nepal.

GoN. 2010. Climatological and Agrometeorological Records of Nepal. Government of Nepal, Ministry of Environment, Science and Technology. Department of Hydrology and Meteorology, Kathmandu, Nepal.

Kumar, A., Bhatt, R. P. and Lakhanpal, T. N. 1990. The Amanitaceae of India. Bishen Singn and Mahendra Pal Singh, Dehradun, India.

Lloyd, C. G. 1808. Mycological Notes. Mycology. Cincinnati, Ohio: Llyod Library and Museum, USA.

Pandey, N. 2008. Mushroom Diversity in Central Nepal: An Ethnomycological Approach: Doctorate Thesis, Tribhuvan University, Kirtipur, Nepal.

Shrestha, K. 1998. Dictionary of Nepalese Plant Names. Mandala Book Point, Kantipath, Kathmandu, Nepal.

Singer, R. 1986. The Agaricales in Modern Taxonomy. 4th edition. Bishen Singh and Mahendra Pal Singh, Dehradun, India.

Stainton, J. D. A. 1972. Forest of Nepal. John Murray Ltd., London, UK. 
Annex 1: Wild macrofungi collected from Baunnakoti Community Forest, Rupandehi District, Nepal

\begin{tabular}{|c|c|c|c|c|c|c|c|c|}
\hline S.N. & $\begin{array}{c}\text { Sample } \\
\text { collection } \\
\text { no. }\end{array}$ & Scientific name & Local name & Order & Family & $\begin{array}{l}\text { Host/ Sub- } \\
\text { stratum }\end{array}$ & Ecology & Application \\
\hline 1 & 100755 & $\begin{array}{l}\text { Amanita caesarea } \\
\text { (Scop.) Pers. }\end{array}$ & Suntale Chyau & Agaricales & Amanitaceae & Soil & Mycorrhizae & Used as vegetable \\
\hline 2 & 100772 & $\begin{array}{l}\text { Amanita chepan- } \\
\text { giana Tulloss \& } \\
\text { Bhandary }\end{array}$ & $\begin{array}{l}\text { Salleu, Kukhu- } \\
\text { ra Phule-chyau }\end{array}$ & Agaricales & Plutaceae & Soil & Mycorrhizae & Used as vegetable \\
\hline 3 & 100773 & $\begin{array}{l}\text { Amanita pan- } \\
\text { tharina (D C.) } \\
\text { Kromb. }\end{array}$ & Bhut Chyau & Agaricales & Amanitaceae & Soil & Mycorrhizae & Deadly poisonous \\
\hline 4 & 1209561 & $\begin{array}{l}\text { Agaricus augus- } \\
\text { tus Fr. }\end{array}$ & Kaile Chyau & Agaricales & Agaricaceae & Soil & Saprophytic & Used as vegetable \\
\hline 5 & 1010524 & $\begin{array}{l}\text { Agaricus sylvi- } \\
\text { cola (Vittad.) } \\
\text { Peck. }\end{array}$ & Sal Chyau & Agaricales & Plutaceae & Soil & Saprophytic & Not edible \\
\hline 6 & 1008149 & $\begin{array}{l}\text { Armellaria Mella } \\
\text { (Vahl.: Fr.) Kum- } \\
\text { mer. }\end{array}$ & Todke Chyau & Agaricales & Marasmiaceae & $\begin{array}{l}\text { On decayed } \\
\text { log from crev- } \\
\text { ices in moist } \\
\text { shady areas }\end{array}$ & Parasitic & $\begin{array}{l}\text { Used as vegeta- } \\
\text { ble/ soup }\end{array}$ \\
\hline 7 & 1007214 & $\begin{array}{l}\text { Asterophora } \\
\text { parasitica (Bull.) } \\
\text { Sing. }\end{array}$ & $\begin{array}{l}\text { Chyau mathi } \\
\text { Seto Chyau }\end{array}$ & $\begin{array}{l}\text { Tricholoma- } \\
\text { tales }\end{array}$ & $\begin{array}{l}\text { Tricholomata- } \\
\text { ceae }\end{array}$ & $\begin{array}{l}\text { In moist shady } \\
\text { place (above } \\
\text { the Russula) }\end{array}$ & Parasitic & Not edible \\
\hline 8 & 1008329 & $\begin{array}{l}\text { Coltricia cin- } \\
\text { ninenea (Pers.) } \\
\text { Murrill. }\end{array}$ & Soli Chyau & $\begin{array}{l}\text { Hymeno- } \\
\text { chaetales }\end{array}$ & $\begin{array}{l}\text { Hymenochae- } \\
\text { taceae }\end{array}$ & $\begin{array}{l}\text { On leaf mould } \\
\text { soil }\end{array}$ & Saprophytic & Not edible \\
\hline 9 & 1009500 & $\begin{array}{l}\text { Cpprinus Coma- } \\
\text { tus (O.F. Mill.) } \\
\text { Pers. }\end{array}$ & Gobre Chyau & Agaricales & Coprinaceae & Soil & Saprophytic & $\begin{array}{l}\text { Edible at young } \\
\text { stage; offered to } \\
\text { child, in the form } \\
\text { of powder mixed } \\
\text { with rice or milk, } \\
\text { for good sleep }\end{array}$ \\
\hline 10 & 100707 & $\begin{array}{l}\text { Coprinus plicati- } \\
\text { lis (Curtis) Fr. }\end{array}$ & Payeje Chyau & Agaricales & Coprinaceae & $\begin{array}{l}\text { On } \log (\text { Aca- } \\
\text { cea catechu })\end{array}$ & Saprophytic & Poisonous \\
\hline 11 & 100708 & $\begin{array}{l}\text { Daldinia concen- } \\
\text { tric (Bolt.) Ces et } \\
\text { de not. }\end{array}$ & $\begin{array}{l}\text { Dalle/ Kale } \\
\text { Chyau }\end{array}$ & Polyporales & Polyporaceae & $\begin{array}{l}\text { On log }(\text { Dal- } \\
\text { bergia sissoo })\end{array}$ & Saprophytic & $\begin{array}{l}\text { Not edible; used } \\
\text { to treat burns }\end{array}$ \\
\hline 12 & 100954 & $\begin{array}{l}\text { Flammulina } \\
\text { velutipes (Curtis) } \\
\text { Sing. }\end{array}$ & Patpate Chyau & Agaricales & Marasmiaceae & $\begin{array}{l}\text { On soil/ de- } \\
\text { caying log }\end{array}$ & Saprophytic & $\begin{array}{l}\text { Edible, but not } \\
\text { popularly used }\end{array}$ \\
\hline 13 & 1007107 & $\begin{array}{l}\text { Ganoderma lucid- } \\
\text { ium P. Karst. }\end{array}$ & Dadhu Chyau & Polyporales & $\begin{array}{l}\text { Ganodermata- } \\
\text { ceae }\end{array}$ & $\begin{array}{l}\text { Trunk (Bom- } \\
\text { bax ceiba) }\end{array}$ & Parasitic & $\begin{array}{l}\text { Used for decora- } \\
\text { tive purpose and } \\
\text { for removing evil } \\
\text { spirit }\end{array}$ \\
\hline 14 & 100759 & $\begin{array}{l}\text { Lentinus tigrinus } \\
\text { (Bull.) Fr. }\end{array}$ & Vedi Chyau & Polyporales & Polyporaceae & $\begin{array}{l}\text { On stump } \\
\text { (Syzygium } \\
\text { cumini) }\end{array}$ & Saprophytic & $\begin{array}{l}\text { Edible, but not } \\
\text { popularly used }\end{array}$ \\
\hline 15 & 1008118 & $\begin{array}{l}\text { Macrolepiota } \\
\text { fuliginosa (Barla) } \\
\text { Bon. }\end{array}$ & Gobre Chyau & Agaricales & Agaricaceae & Soil & Saprophytic & Used as vegetable \\
\hline 16 & 1008330 & $\begin{array}{l}\text { Macrolepiota } \\
\text { rhacodes (Vittad.) } \\
\text { Sing. }\end{array}$ & Gobre Chyau & Agaricales & Agaricaceae & Soil & Saprophytic & Used as vegetable \\
\hline 17 & 1008315 & $\begin{array}{l}\text { Nigroporus } \\
\text { vinosa (Berk.) } \\
\text { Murrill }\end{array}$ & Jhule Chyau & Polyporales & $\begin{array}{l}\text { Fomotopsida- } \\
\text { ceae }\end{array}$ & $\begin{array}{l}\text { On } \log (\text { Syzy- } \\
\text { gium cumini })\end{array}$ & $\begin{array}{l}\text { Parasite/ } \\
\text { Saprophyte }\end{array}$ & Not edible \\
\hline
\end{tabular}


100711 Pycnoporus cin- Sindure Chyau Polyporales Polyporaceae nabarinus (Jacq.)

P. Karst.

19

1007171 Russula emetica (Schaeff.) Pers.

20

1008350 Russula foetens

Pers.

Gandhe

Russulales Russulaceae Soil

Chyau

Stump (Syzy-

gium cumini)

Saprophytic

Used for relief

of ear pain and mumps
$21 \quad 100751 \quad$ Russula nigri- cans Fr.

Handi Chyau

Russulales

Russulaceae Soil

22

101002 Schizophyllum Pankha commune Fr: $\quad$ Chyau Fr.
Agaricales Schizophyl- Decayed laceae
wood

(Shorea

robusta)

23

1009152 Scleroderma bovista Pers.

$$
\text { Alu Chyau, }
$$
Ptteu

Bolatales

Scleroder-

Soil

mataceae

Dalle Chyau

Bolatales

Scleroder-

Soil citrinum Fr. mataceae

Dhamere

Chyau, Vemti

Agaricales

Tricholoma

Termites nest Sapro-

Heim.

261007119 Termitomyces

eurhizeus

Dhamere/

Bagale

(Berk.) Heim.

Chyau

27

1109856 Volvorella volvacea (Bull.:Fr.)

Parale Chyau Agaricales Plutaceae Sing.

decomposed Sapropaddy straw phytic phytic

Poisonous medicine that causes vomiting

Mycorrhi- Poisonous zae

Mycorrhi- Edible; used as zae pickles

Sapro- Edible; used phytic for culinary purpose; has religious/ cultural values

Mycorhi- Edible; used zae as vegetable; has medicinal values

Mycorhi- Not edible; zae causes gastric disorders or acute indigestion

Edible; used for treatment of feaver and measles

Edible; used for treatment of feaver and measles

Used as vegetable 